\title{
Anti-Trafficking in the Commonwealth of Independent States: The Main Areas and Mechanism of International Cooperation
}

\author{
Alexey Vladimirovich, Boretsky \\ Innovative University of Eurasia, Kazakhstan, 140000, Pavlodar, M. Gorky Street, 102/4 \\ Email: alexey1977.77@mail.ru \\ Sergey Gennadjevich, Pen \\ Kazakh Humanitarian Law University, Kazakhstan, 010000, Astana, Korgalzhyn Street, 8 \\ Email: cpen@mail.ru

\section{Alexander Vladimirovich, Borovkov} \\ Volgograd State University, Russia, 400062, Volgograd, University Avenue, 100 \\ Email: borovkovav@rambler.ru
}

Doi:10.5901/mjss.2015.v6n3s1p94

\begin{abstract}
As a rule, the crimes related to trafficking in human beings are transnational in nature, therefore the international law enforcement cooperation in counteraction against human trafficking, committed in their territories, acquire particular importance in detection and investigation of trafficking in persons. The purpose of this article is to review the main possible areas of international cooperation of the law enforcement agencies of the Commonwealth of Independent States in combating human trafficking. The authors, based on an analysis of the existing international instruments to combat trafficking in persons, reveal details of the main directions of the international cooperation of the CIS countries' law enforcement bodies, implemented through: the partial transfer of competence, a joint investigation of criminal cases, as well as the extradition of a person for criminal prosecution. In addition, the authors make an attempt to investigate the mechanism of international law enforcement cooperation in combating human trafficking.
\end{abstract}

Keywords: human trafficking, international cooperation in the fight against crime, the Commonwealth of Independent States, transnational crime, human trafficking investigation.

\section{Introduction}

In the international law human trafficking is estimated as a criminal activity, controlled by transnational criminal organizations, entailing serious consequences to the safety of an individual, society and the state, serious human rights violations and bringing criminals substantial illegal profits.

Trafficking in human beings almost always is transnational in nature. In this case, its detection and investigation is practically impossible without the cooperation of the law enforcement agencies of a separate state with similar bodies in other countries. Law enforcement cooperation, including anti-trafficking, should always be considered as a stage of international cooperation between states, and as an institution that provides legal implementation of international agreements.

However, law enforcement cooperation always takes place in the context of the overall cultural and economic cooperation, for example, on a background of migration flows of various kinds.

This is directly related to the interstate cooperation of the Commonwealth of Independent States, as the CIS includes states with common historical and cultural roots, and that experience similar economic and political processes after the collapse of the USSR and gaining independence.

Historically, the international law enforcement cooperation corresponds to other forms of global cooperation, especially cooperation in the area of criminal law and human rights, being in fact a criterion of such cooperation.

The international law enforcement cooperation is a legal means to solve such tasks as prevention of crimes concealment and the results of their committing abroad, criminals fleeing abroad, the solution of crimes committed 
abroad, the detection of crimes that began in one country and were completed in another. It is used to implement the principle of inevitability of punishment for a crime.

The study of international law enforcement cooperation is extremely important, as it allows to consider a number of new forms and methods of criminal activity generated by the development of communication, increasing migration flows, the complexity and internationalization of business processes.

Selected issues of international cooperation to combat trafficking in human beings were considered by such authors as L. D. Erokhina (2012), D. M. Hughes (2002), L. I. Shelley (2010), S. W. Stoecker (2010), A. V. Boretsky and S. K. Zhetpisov (2013), M. Farley (2003), and other authors.

In addition, some of the problems of international cooperation of the CIS member states in the field of combating trafficking in persons were previously studied by E. V. Mizulina (2006), B. M. Nurgaliyev et al. (2014), P. D. Bilenchuk et al. (1999), as well as T. A. Khanov and A. V. Boretsky (2012).

Despite all the previous studies, there was not given a detailed analysis of the mechanism of international cooperation against trafficking in human beings in general, and particularly in the Commonwealth of Independent States, which indicates the need for further research in this area.

\section{Research Methods}

In the methodological basis of the study lies the system of common, separate and special methodological principles, approaches and methods of scientific cognition, applicable either separately or in combination with each other. In particular, there have been used such methods as dialectical, historical, comparative analysis, simulation, statistical and systematic-structural, action and situational approaches to the study of the processes and phenomena.

In addition, the study used sociological techniques such as questionnaires and interviews with the victims, law enforcement officials and representatives of the crisis centers.

In the course of the present study, there was made an analysis of the criminal cases of human trafficking, considered in the courts and being under criminal proceedings, with the purpose of exposure of the investigation deficiencies and errors, committed by the investigation subjects.

In order to achieve the objective results of the study these methods were applied comprehensively.

\section{Regulatory Framework and the Main Directions of International Cooperation in Combating Human Trafficking}

The countries of the former Soviet Union are now actively declaring the need to combat human trafficking. The CIS countries take joint integrated legal, socio-economic, information and other measures to combat human trafficking, as well as the measures to protect victims of trafficking and rehabilitate them.

In particular, a number of international treaties and agreements have been adopted in the framework of the Commonwealth of Independent States, such as, Convention "On Legal Assistance and Legal Relations in Civil, Family and Criminal Matters" (2002), an Agreement on "Cooperation of states-members of the Commonwealth of Independent States in the fight against trafficking in human beings, human organs and tissues" (2005), the Decision of the Council of Heads of States "On cooperation Programme of the Commonwealth of Independent States in the fight against trafficking in human beings for 2014-2018" (2013). assistance:

The mentioned international instruments of the CIS in the aggregate provide the following types of mutual legal

- Obtaining testimony and statements from individuals (including the accused, suspects, witnesses, victims, experts, and others);

- Provision of detainees or other persons to give testimony or assist in the investigations;

- Delivery of the documents, relating to the criminal proceedings, including subpoenas;

- Execution of searches and seizures;

- Execution of inspections, including forensic;

- Providing information, evidence, originals or certified copies of relevant documents and records, including bank, financial, legal, and business;

- Identification and location of persons;

- Expert examination;

- Identification or detection of profits, property, assets or other things, their transfer for evidentiary purposes, as well as the implementation of measures related to the arrest, seizure and transfer of property, obtained by 
crime, restitution and recovery of fines;

- Provision of any assistance that is not contrary to the domestic law of the requested state;

- Use of the videoconferencing technology in the investigation and criminal proceedings;

- Carrying out cross-border search and seizure of information, transmitted over telecommunications networks;

- Taking measures to locate, identify, arrest, seize and confiscatethe funds, intended for the purposes of terrorism and others.

The foregoing suggests that the interaction of states on legal assistance in criminal matters, including human trafficking, takes place by:

- Partial transfer of competence;

- Joint investigation in criminal cases (participation of a representative of a foreign state in the inquiry, or creation of the joint investigative teams);

- Extradition of a person for criminal prosecution.

\section{Implementation of Legal Assistance Through the Transfer of Competence}

The transfer of competence is typical for mutual legal assistance in criminal matters, which distinguishes it from the other types of international cooperation: the joint investigation of criminal cases and extradition of a person for criminal prosecution.

If necessary, the investigative actions abroad, collection of evidence, etc. are carried out by competent authorities of a foreign state in accordance with its domestic law at the request of the Republic of Kazakhstan on legal aid. Such activities are not a direct part of the criminal proceedings in the territory of the Republic of Kazakhstan. However, it belongs to the regulated relations, and is carried out by the partial transfer of jurisdiction to another state to obtain evidence, implement the procedural actions and execute search operations on their own criminal case. Thus, according to the criminal case on the fact of exploitation of an Ukrainian citizen V. Belokonov in the village Karamendy, Naurzum district of Kostanai region, the preliminary investigation body has sent a request for international legal assistance to the AIA of Lugansk region to provide documents proving the identity of the victim, who had lost them (Kolokolova O., 2007).

Execution of the requests for legal assistance, received from foreign countries, also extends beyond the criminal justice system, limited to the country where the investigation is carried out, by the pretrial and trial proceedings in a criminal case. In this case, a foreign state also delegates a part of its authority in the criminal case, since the execution of the request relates to the criminal case, under the foreign proceedings (Feoktistova E. E., 2006).

Transfer of authority implies the opportunity of the competent authorities of a foreign state to obtain evidence on its own criminal case. They also decide on the most rational plan of action to establish the necessary facts and to obtain the required evidence. The evidence obtained under the foreign criminal procedure law, are declared admissible and meeting the requirements of national law of the requesting state, unless otherwise provided by the relevant international treaties.

In our view, it is possible to agree with M. I. Smirnov, according to whom, the actual transfer of authority in the provision of legal aid does not occur. "Since the "delegation of authority" by one state requires mandatory "acceptance of authority" by others. In the international cooperation such unconditional transfer does not occur. The requested state, in response to a request for assistance, first agrees to help, and then delivers it within its legislation. The requesting state may not take advantage of this assistance (for example, the obtained evidence contradicts its own legislation)" (Smirnov M. I., 2004).

The transfer of authority is not applied in the criminal prosecutions in the territory of another state or extradition for prosecution. Thus, upon institution of criminal prosecution in another state, all the procedural actions and decisions depend exclusively on the discretion of the state directly involved in this pursuit. In extradition of a person for criminal prosecution the requested state only makes a decision on the possibility or impossibility of delivering a specific person, that decision making does not essentially affect the position of the investigation bodies concerning the circumstances of the crime.

As mentioned above, more crimes affecting the interests of several states are committed recently. Transnational trafficking in persons applies to these crimes. They require a new level of cooperation - not just the transfer of authority to the requested state, but its joint implementation.

\section{Joint Investigation of Criminal Cases Involving Human Trafficking}

A representative of a foreign state may be present at executing the request of that state, if it is provided by an 
international treaty or a written commitment to cooperation based on the principle of reciprocity.

The requests for the attendance of such officials or interested persons should not be refused if such presence is likely to serve the needs of the requesting state in legal assistance and thereby avoiding additional requests for assistance.

At the petition of the requesting state, the requested state promptly informs it of the time and place of execution of the request so that the authorized representatives could be present, with the consent of the state institutions of justice and in accordance with its laws; and take part in the production of proceedings and investigation activities, if it is not contrary to the law of the requested state. In this case, information about representatives of foreign states that are present in the production of the procedural action shall be registered in the protocol.

Regulations for participation of the representatives of foreign states in the execution of the requests are explicitly enshrined in the criminal procedure legislation of the CIS member states.

In presence of the grounds for a joint investigation of the facts of human trafficking by the competent authorities of a state, a proposition to establish a joint investigation group is made to the competent authority of another state. Currently, the establishment of a joint intergovernmental investigative team is governed by Art. 63 of the Convention "On Legal Assistance and Legal Relations in Civil, Family and Criminal Matters" (2002), the United Nations Convention against Transnational Organized Crime (2000). An example of this form of international cooperation is the joint RussianKazakh investigation, which took place in Yekaterinburg city (Russian Federation), when in one of the Ekaterinburg bathhouses there were detained Russian citizens, engaged in the export of Kazakhstan girls from Rudny city of Kostanai region intended to provide intimate services in Yekaterinburg. In consequence, these persons were prosecuted under Art. 127-1 of the Criminal Code of the Russian Federation (Zhuravlev S.Yu., and Pigajev A.M., 2006).

The basis for creating an investigative team is a prompt and thorough investigation of crimes committed by one or more persons on the territory of two or more Contracting States or concerning them.

A joint investigative team is usually created for a limited period of time, which might be extended by mutual consent of the parties involved.

The creation of a joint investigative team is possible, if:

- a criminal case on trafficking, requiring difficult cross-proceedings in close cooperation with foreign states is in the execution of one country;

- several states conduct the investigation of criminal cases of human trafficking which circumstances inevitably entail coordinated actions of the states involved.

A request to establish the joint investigation team can be made by any interested state. After receiving the proposal, the competent authorities of the requested state shall,within 15 days, notify the relevant authorities of the requesting party of the decision; and in case of consent simultaneously provide them with a list of the officials included in that group.

The states conclude an Agreement to establish a joint investigative group (JIG), which in addition to the basic details, goals, objectives of creating such a group, shall include: the head, the specific performers, their number and responsibilities, logistical and financial support. The investigative team is recruited from experienced, the most qualified law enforcement officials of the participating states.

Coordination of the joint investigation group'sactivities is exercised by a representative of the competent authority of the state hosting the operation. The head of the group operates within its competence under national law.

In the presence of several criminal cases in different states, (by mutual consent of the competent authorities of all participating states) the supervision of a JIG is exercised by a representative of the competent judicial authorities, engaged in the most serious crimes, or who are supposed to conclude the joint investigation of the case.

The investigative team carries out its activities in accordance with the laws of the state hosting the operation. The terms of investigation are calculated in accordance with the law of that state.

The members of the investigation group can directly interact with each other, coordinate the basic lines of inquiry, conduct investigative actions, or operational search activities, share the obtained information under the control of the head of the group.

At the same time, the authority of the participants from the hosting country is much wider than the actions of the members from other states.

The members of the joint investigation team from the other states-members are entitled to participate in the investigative operations. In this case, the team leader may, for particular reasons, in accordance with the laws of the hosting state, decide otherwise. At the same time, the team leader may assign said participants of the joint investigation to the task of taking certain investigative measures, in accordance with the law of the State hosting the operations, if approved by the competent authorities of the hosting state and the second state. 
It should be noted that, despite the restrictions on the powers, the members of the joint investigation from the other participating states are considered to be the officials carrying out the operations in respect of the offenses committed against or by them.

During an investigation conducted by the joint investigative team in the territory of one state, it may be necessary to conduct investigative actions, search operations on the territory of another state-member of such a group. In this case, participants of the joint investigation from the other member-states may request their competent authorities to take such measures. These measures are considered to be susceptive to the conditions which would apply if they were requested in a national investigation.

If the joint investigation team requires assistance of a country not involved in its creation or a third party, the competent authorities make the request for assistance in accordance with current laws or agreements between these states.

The decision to disband the joint investigation group, to replace the employees, their tenure in the group is taken by mutual agreement of the competent authorities of all participating states.

At the same time, as P. D. Bilenchuk, S. E. Erkenov and A. V. Kofanov fairly state, "while establishing joint units it is expedient to solve a number of technological problems, primarily, criminal procedural issues" (Bilenchuk P. D. et al., 1999).

Investigative actions and operational-search activities shall be conducted by employees of an interstate unit (investigative group) with the consent of a special prosecutor with subsequent notification of the prosecutor at the venue of the investigative action or operational-search activities.

Enforcement investigations should be carried out with the obligatory participation of the law enforcement authorities of the host country.

Search operations involving undercover employees and full-time law enforcement officers working «undercover» in the framework of joint units, can be carried out in the interests of disclosure and investigation of crimes on the territory of several countries participating in the agreement.

The head of the joint unit, receiving information about the investigative actions and operational-search activities results from the employees of national law enforcement authorities is entitled to use it in the work of the international police unit, but may not transfer it to the law enforcement officials in other countries. The international division members must be specifically notified about this, right up to a possible criminal prosecution.

A very important aspect of the joint efforts to combat transnational crime - is the use of special knowledge. If the use of special knowledge in the investigative actions, operational-search activities, special studies, in advisory activities of knowledgeable persons and direct application of special knowledge by the employees of interstate units will not cause particular difficulty, then the issue of the forensic examinations requires independent resolution (Erkenov S. E., 2000).

Let's consider the following component of the international cooperation in criminal cases of human trafficking prosecution.

The value of this type of cooperation in criminal matters cannot be overestimated, because prosecution is an activity implying limitation of the constitutional rights of citizens, and its results tend to entail quite serious consequences for individuals.

The agreements on legal assistance contain a provision stating that each contracting state shall, at the request of a second contracting state, in accordance with its law, initiate criminal proceedings against its citizens suspected of committing crimes on the territory of the secondcontracting state. In this case, the prosecution in the requested state may be carried out, provided that the act is a criminal offense in this country.

The base for enquiry is the impossibility of carrying out a comprehensive investigation in a foreign country in the absence of the person, subject to prosecution in the territory of this foreign state. For example, the internal affairs department of the city of Almaty has had initiated proceedings under Art. 128 of the Criminal Code RK against K. Karimbaev, engaged in the export of kazakh girls to Switzerland through the territory of the Russian Federation. A criminal case was initiated at the request of the law enforcement authorities of the Russian Federation (Umarov A., 2001).

The need to address the issues related to criminal prosecution, also arises in cases when the accused hides in another state after committing the crime and his extradition is required, as well as in case of refusal to extradition request.

Thus, in case of refusal to the extradition request by the state, it must, in accordance with its law, carry out the prosecution of its own citizens, who have committed a crime in another state. The initiator of the criminal prosecution in this case is the native country of such person. But without the written consent of the foreign state, having jurisdiction over the citizen, his native country is unqualified to prosecute the non-extradited person. Thus, there is a partial concession of sovereignty to a foreign state with the right of that country to apply their national legislation in the prosecution for a crime committed outside its territory. 
It should be noted that the transfer of criminal prosecution differs from the international legal assistance, as well as from the extradition of persons both in objectives and legal implications, and at the transfer procedure itself.

For example, in rendering international legal support a criminal case is initiated, investigated and analyzed substantively in the state, requiring assistance. The final decision is made on behalf of the same state. The results of international legal assistance have no independent meaning outside the context of a criminal case.

All relations concerning the criminal proceedings are carried out through the central authorities of the contracting states which are specified in the relevant international treaties and norms of the internal legislation of the $\mathrm{CIS}$ member states.

In accordance with the agreements on legal assistance for criminal prosecution, the central authorities of the contracting states may receive both the criminal case and the criminal prosecution.

In directing the criminal case by the requesting state, the investigation of the case is continued by the requested state in accordance with its domestic law. Before issuing the order on prosecution the requesting state shall perform the appropriate volume of investigative actions, which confirm the validity of the prosecution by this country and the possibility of continuing it in the native country of the accused, as well as address the issue of extension of the investigation, detention of the accused and the resumption of the proceedings.

After acceptance of the criminal case for prosecution by the requested state, the requesting state may not involve a suspect, accused person to responsibility for the act in question.

It should be noted that in the course of prosecution it is possible to exceed the limits of the circumstances mentioned in the request. In this case, in our opinion, this situation should be resolved on the basis of the international treaties' provisions that the prosecution and the criminal investigation is carried out, as a rule, in accordance with the domestic legislation of the contracting states. This means that the bodies of the preliminary investigation of a separate state should not be bound by the requirements to prosecution against specific individuals for certain acts. Investigators or investigative bodies have the right to bring charges against a greater number of persons than is mentioned in the request for criminal prosecution, as well as to charge other citizens of this state that are abroad.

Thus, we can conclude that at the grounds of the request for prosecution lie the following conditions: the perpetrator of human trafficking must be a citizen of the CIS state; trafficking should be committed in the territory of a foreign country; the offender must return to the territory of the state of citizenship.

\section{Extradition of a Person for Criminal Prosecution}

One of the most important components of international cooperation in criminal matters is extradition of persons. This form of international cooperation is one of the most common in the practice of criminal investigation on trafficking in persons, in connection with the fact, that often the perpetrators are in the territory of other states. For example, the question of extradition to the territory of the Republic of Kazakhstan has occurred in the criminal case of recruitment of people by an organized criminal group, led by a Davydova, engaged in export of minor female pupils of SI Lyceum №8 of Lobanovo village, Aiyrtau district of the North-Kazakhstan region to the Kokshetau city, where the victims were exposed to sexual exploitation in saunas and baths. Subsequently, Davydova was arrested on the territory of the Russian Federation, where a request for her extradition was sent. Moreover, the DIA of Zhambyl region, due to the decision of the perpetrator's extradition issue, had suspended the proceedings in criminal case against Musabekova, living in the UAE, who exported kazakh girls and women to the UAE, to provide sexual services (Reference on the investigation status of the criminal cases related to human trafficking, by internal affairs agencies, 2010).

The relationships between states on extradition are regulated through:

- the international conventions and treaties on legal assistance, which provide for the extradition of persons who have committed crimes, in accordance with the procedure and under the conditions specified by the contracting parties;

- the national law of the contracting states.

At the same time, international courtesy is applied, according to which, satisfaction of a request for extradition is an act of voluntary decision of one state toward another, including in the terms of provision of the mutual legal assistance of this kind (Volzhenkina V. M., 1999).

The issue of extradition may be made under the following conditions only:

- the requesting state is authorized to exercise criminal jurisdiction in respect of a person whose extradition is sought, in accordance with its domestic law;

- the committed crime should be punished by imprisonment under the law of both the requesting and the 
requested states;

- the committed crime should provide for imprisonment for not less than one year or a heavier penalty when the extradition is requested for institution of criminal proceedings, and not less than six months' imprisonment or a heavier penalty, if extradition is requested for the execution of the court sentence, which has hadentered into force.

The official bodies qualified to deal with the issues of extradition in the CIS countries, as a rule, are the general prosecutor's offices of these states.

The preliminary investigation bodies do not make a directdecision on extradition. Their functions in executing a request for extradition is largely limited to activities related to the arrest (if it is entrusted to the investigating authorities), addressing the issue of extension of detention, carrying out "occasional" investigative activities and providing a defender.

In accordance with the international law and national legislation, sending an extradition request abroad by the investigating authorities should be based on: the established offense, the time and place of its commission; finding the person who had committed a criminal offense, punishable by imprisonment; sufficient evidence proving the person to be extradited guilty of the crime; theadopted decision to prosecute the person to be extradited as an accused.

One of the main issues subject to a thorough examination, when considering a request for extradition or sending the same inquiry, is to establish the nationality of the person requested to face extradition.

Thus, the legal basis for applying for international legal assistance are the rules of the national criminal procedure and other branch legislation, international treaties ratified and entered into force, multinational conventions and other international agreements.

\section{Conclusions}

In cases of human trafficking, rendering international legal assistance in the framework of the CIS is required in all cases where the offender is a citizen of one state and (or) commission of a crime is connected with the export of people outside of a state-member of the $\mathrm{CIS}$.

Organized criminal groups involved in human trafficking, operate in the territory of two or more states. As a general rule, selection, recruitment and transportation are carried out on the territory of one state, and receiving, finding a buyer, sale, exploitation - on the territory of another state.

The international instruments of the Commonwealth of Independent States in the aggregate provide the following types of mutual legal assistance:

- Obtaining testimony and statements from individuals (including the accused, suspects, witnesses, victims, experts, and others);

- Provision of detainees or other persons to give testimony or assist in the investigations;

- Delivery of the documents, relating to the criminal proceedings, including subpoenas;

- Execution of searches and seizures;

- Execution of inspections, including forensic;

- Providing information, evidence, originals or certified copies of relevant documents and records, including bank, financial, legal, and business;

- Identification and location of persons;

- Expert examination;

- Identification or detection of profits, property, assets or other things, their transfer for evidentiary purposes, as well as the implementation of measures related to the arrest, seizure and transfer of property, obtained by crime, restitution and recovery of fines;

- Provision of any assistance that is not contrary to the domestic law of the requested state;

- Use of the videoconferencing technology in the investigation and criminal proceedings;

- Carrying out cross-border search and seizure of information, transmitted over telecommunications networks;

- Taking measures to locate, identify, arrest, seize and confiscate the funds, intended for the purposes of terrorism and others.

The interaction of states on legal assistance in criminal matters, including human trafficking, takes place by:

- Partial transfer of competence;

- Joint investigation in criminal cases (participation of a representative of a foreign state in the inquiry, or creation of the joint investigative teams);

- Extradition of a person for criminal prosecution. 
Therefore, the abovementioned forms of cooperation during the investigation of the crimes in questionare, undoubtedly, the most appropriate and effective. This is confirmed by the practice of law enforcement cooperation in the investigation of human trafficking cases.

\section{References}

Agreement on cooperation of the CIS member states in the fight against human trafficking, human organs and tissues. Signed on November 25, 2005. [Online] Available: http://cis.minsk.by/reestr//ru/index.htm/\#reestr/view/text?Doc-1901.

Bilenchuk, P. D., Erkenov S. E., Kofanov A. V. (1999) The Transnational Crime. State and transformation. Kiev. Atika.

Boretsky A. V., Zhetpisov S. K. (2013) Combating Human Trafficking: Cooperation of the Middle East Countries and the Republic of Kazakhstan. Middle-East Journal of Scientific Research, 14(11), 1422-1427.

Convention on legal assistance and legal relations in civil, family and criminal matters (Kishinev Convention). Signed on October 7 , 2002. [Online] Available: http://online.zakon.kz/Document/?doc_id=1034672.

Decision of the Council of Heads of State "On the Program of cooperation of the Commonwealth of Independent States in Combating Human Trafficking for 2014-2018" dated October 25, 2013. [Online] Available: http://www.e-cis.info/page.php?id=23806.

Erkenov, S. E. (2000) The interaction of law enforcement bodies of the CIS countries in the detection and investigation of transnational crime. (Dissertation of Doctor Juridical Sciences). Moscow.

Erokhina, L. D. (2012) The globalization of international trafficking in women and organized prostitution in South-Eastern countries. Current studies of social problems, 5(13). [Online] Available: http://sisp.nkras.ru/e-ru/issues/2012/5/ erokhina.pdf.

Farley, M. (2003) Prostitution, Trafficking and Traumatic Stress. New York. Routledge.

Feoktistova, E. E. (2006) International cooperation of the preliminary investigation bodies in criminal cases: procedure and forensic aspects (Dissertation of Candidate Juridical Sciences). Moscow.

Hughes, D. M. (2002) The use of New communications and Information Technologies for Sexual Exploitation of Women and Children. Hastings Women's Law Journal, 13(1), 129-148.

Khanov, T. A., Boretsky, A. V. (2012). Interaction of the Russian Federation and the Republic of Kazakhstan in combating crimes related to human trafficking. Criminology Journal of Baikal National University of Economics and Law, 4, 76-81.

Kolokolova, O. (2007) Charity slavery. Caravan. October 26th.

Mizulina, E. B. (2006) Human trafficking and slavery in Russia: international legal aspect. Moscow. Yurist.

Nurgaliyev, B. M., Lakbayev, K. S., Kussainova, A. K. and Boretsky, A. V. (2014) Impact of Organized Crime on Shadow Economy: Social Impact Assessment. Asian Journal of Applied Sciences, 7(7), 644-651.

Reference on the investigation status of the criminal cases related to human trafficking, by internal affairs agencies in 2009. Pavlodar. Department of Internal Affairs of Pavlodar region.

Shelley, L.I. (2010) Human Trafficking: A Global Perspective. Cambridge: University Press.

Smirnov, M. I. (2004) The concept and the current state of the institution of mutual legal assistance in criminal matters. Pravovedenie, 5, $162-171$.

Stoecker, S.W. (2010) Human Traffic And Transnational Crime: Eurasian And American Perspectives. Oxford: Rowman \& Littlefield.

Umarov, A. (2001) Unlucky pimp. Moscow News, April 9th.

United Nations Convention against Transnational Organized Crime. Adopted November 15, 2000. [Online] Available: http://online. zakon.kz/Document/?doc_id=1025333.

Volzhenkina, V. M. (1999) Application of the rules of international law in the Russian Criminal procedure: problems of the theory and practice (Dissertation of Candidate Juridical Sciences). Moscow. 